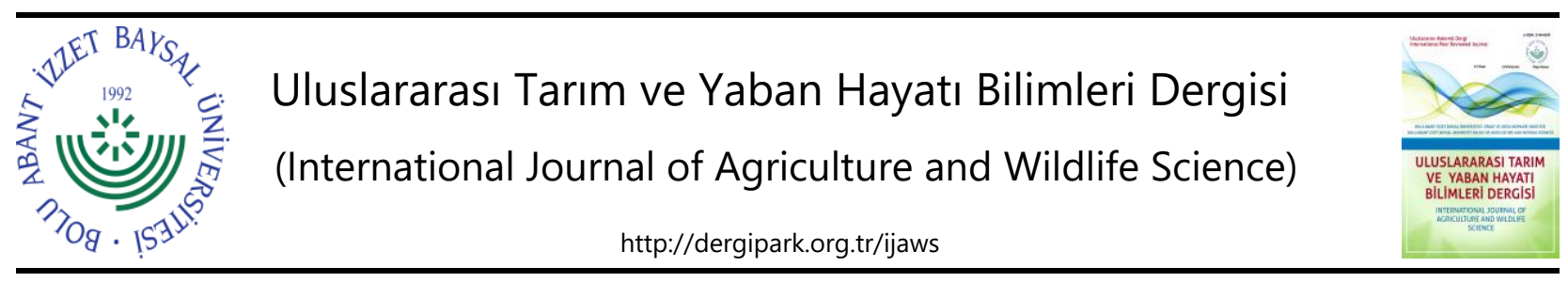

Araştırma Makalesi

\title{
TR61 Bölgesinde Genç Çiftçi Projesi Desteğinden Yararlanmayı Etkileyen Faktörlerin Değerlendirilmesi
}

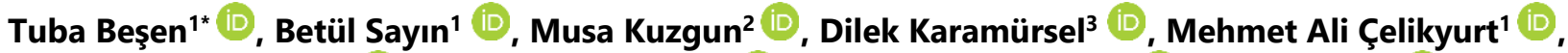 Meltem Emre $^{4}$ (D) Fatma Pınar Öztürk ${ }^{3}$ iD , Şerife Gülden Yılmaz ${ }^{1}$ iD , Duygu Birol ${ }^{5}$}

\author{
${ }^{1}$ Tarım ve Orman Bakanlığı, Batı Akdeniz Tarımsal Araştırma Enstitüsü, 07100, Antalya \\ ${ }^{2}$ Tarım ve Orman Bakanlığı, Gündoğmuş İlçe Tarım Müdürlüğü, 07860, Antalya \\ ${ }^{3}$ Tarım ve Orman Bakanlığı, Meyvecilik Araştırma Enstitüsü, 32500, Isparta \\ ${ }^{4}$ Tarım ve Orman Bakanlığı, Zeytincilik Araştırma Enstitüsü, 35100, İzmir \\ ${ }^{5}$ Tarım ve Orman Bakanlığı, İncir Araştırma Enstitüsü Müdürlüğü, 09600, Aydın
}

Geliş tarihi (Received): 09.12.2020 Kabul tarihi (Accepted): 20.01.2021

\section{Anahtar kelimeler: \\ Genç çiftçi, tarımsal destek, lojistik regresyon, TR61Bölgesi, Türkiye.}

Özet. Çalışma, TR61 Bölgesinde üreticilerin Genç Çiftçi Projesi desteklerinden yaralanmasını etkileyen faktörlerin belirlenmesi, genç çiftçilerin ve işletmelerinin özelliklerinin ortaya konulması amacıyla yapılmıştır. Çalışmanın hedef kitlesini destekten yararlanmış üreticiler ile yararlanmamış üreticiler oluşturmaktadır. Çalışmanın materyali, bu destekten yararlanan üreticilerden örnekleme yoluyla seçilenler 72 üretici ve karşıt grup olarak aynı yaş grubundaki 72 üretici ile yüz yüze yapılan anketlerden elde edilen verilerden oluşmaktadır. Araştırmada destekten yararlanan ve yaralanmayan üreticilerin ve sahip oldukları işletmelerin özellikleri tanımlayıcı parametreler (minimum, maksimum, ortalama değerler, yüzde oranlar) ile ortaya koyulmuştur. Destekten yararlanan ve yararlanmayan üretici grupları arasındaki farklılıkların tespitinde kesikli verilerde Ki-kare testi, normal dağılım göstermeyen sürekli verilerde Mann-Whitney $U$ testi kullanılmıştır. Destek almayı etkileyen faktörlerin belirlenmesinde íkili Lojistik Regresyon analizi kullanılmıştır. TR61 Bölgesinde, üreticilerin cinsiyet, medeni durum, tarımsal örgüte üye olma durumu ve tarım dışı gelir sahipliğinin, genç çiftçi desteklerinden yararlanmada etkili olduğu belirlenmiştir. Tarım ve Orman Bakanlığı tarafından genç çiftçilere verilen desteklemeler büyük önem arz etmektedir. Genç çiftçi destekleri alana özel çeşitlendirilerek devamlıı̆ı sağlanmalıdır. Genç çiftçi desteğinden yararlanmış olan üreticilerin yaptıkları faaliyetleri geliştirmelerine yönelik eğitimler, genç çiftçileri bir araya getirebilecek farklı örgütlenme modellerinin geliştirilmesi, pazara ulaşmada kolaylık sağlayacak öncelikler, dijital pazarlama yöntemlerinin yaygınlaştırıması gibi ek destekler de verilen genç çiftçi desteğinin etkinliğini artıracaktır.

\section{Evaluation of the Factors Affecting to Utilization Young Farmer Project Support in TR61 Region}

\begin{abstract}
Keywords:
Young farmers, agricultural support, logistic reggression, TR61 Region, Turkey
\end{abstract}




\section{GiRiş}

Tarım, kırsal alanlarda yaşayan ve çoğunlukla çiftçilikle uğraşan dünyadaki yoksulların \%80'i için yoksulluğun azaltılmasına, gelirlerin artırılmasına ve gıda güvenliğinin iyileştirilmesine yardımcı olmaktadır. Bu da, tarımsal kalkınmayı, aşırı yoksulluğu sona erdirmek, paylaşılan refahı artırmak ve 2050 yılına kadar tahmini 9.7 milyar insanı beslemek için en güçlü araçlardan biri haline getirmektedir. Tarım sektöründeki büyüme, diğer sektörlere kıyasla en yoksul kesimin gelirini artırmada iki ila dört kat daha etkilidir (DB, 2020). 2016 yılındaki analizler, çalışan yoksul yetişkinlerin \%65'inin geçimini tarım yoluyla sağladığını ortaya koymaktadır. Tarım, ekonomik büyüme için de çok önemlidir: 2018'de küresel gayri safi yurtiçi hasılanın (GSYiH) \%4'ünü oluştururken, bazı gelişmekte olan ülkelerde GSYiH'nın \%25'inden fazlasını oluşturabilmektedir (DB, 2020). Türkiye'de tarımın GSYiH içindeki payı 2018 yılında \%5.82 olarak gerçekleşmiştir (TÜiK, 2020).

Yapılan tahminler, yaklaşık 690 milyon insanın aç olduğu, dünya nüfusunun \%8.9'unun bir yılda 10 milyon kişi ve beş yılda yaklaşık 60 milyon kişi arttığı yönündedir. Açlığa yaklaşan bir başka ölçü olan şiddetli gıda güvensizliğinden etkilenen insan sayısı da benzer bir artış eğilimi göstermektedir. 2019'da yaklaşık 750 milyon kişi diğer bir ifadeyle dünyadaki her on kişiden biri ciddi düzeyde gıda güvensizliğine maruz kalmıştır. Orta veya şiddetli gıda güvensizliğinden etkilenen toplam sayı göz önüne alındığında, 2019'da dünyada tahmini 2 milyar insan güvenli, besleyici ve yeterli gıdaya düzenli şekilde erişememiştir. Yapılan ön değerlendirmeler, COVID-19 salgınının, ekonomik büyüme senaryosuna bağlı olarak 2020'de dünyadaki toplam yetersiz beslenen insan sayısına 83 ila 132 milyon kişi ekleyebileceğini göstermektedir (FAO, 2020a).

Türkiye 2019 nüfusu, 2007 yılına göre \%17.80 artarak 83155 000'e ulaşmıştır (TÜiK, 2020). Artan nüfus ve kişi başı artan tüketim miktarı, Türkiye'de gıda talebini artırmaktadır. Ülkenin gıda güvenliğinin sağlanması için tarım sektörünün sürdürülebilirliğinin sağlanması gerekmektedir.

Türkiye'de kırsal kesim incelendiğinde; yaklaşık 21 milyon büyüklüğünde kırsal nüfusa; 2.5 - 3 milyon arasında değişen tarımsal işletmeye; 5 - 5.5 milyon arasında değişen tarımsal istihdama ve 36 binden fazla köy yerleşimine (beldeler dâhil) sahip olduğu görülmektedir (Anonim, 2018). Haziran 2020 itibariyle 4769000 kişi tarımda istihdam edilmektedir (TÜiK, 2020).

2014 yılında 2533000 olan tarımda çalışan kadın sayısı 2019 yııında \%13.03 azalarak 2241 000'e, toplam tarımsal istihdam içindeki payı \%46.31'den \%43.97'ye gerilemiştir. Aynı dönem içinde, tarımda istihdam edilen erkek oranı \%2.84 düşüş göstermiştir. Tarım dışı sektörde dağılım incelendiğinde; 2014 yılında 5156000 olan kadın çalışan miktarı 2019 yılında \%22.85 artarak 6683 000'e çıkmış, toplam tarım dışı istihdam içindeki payı \%25.20'den \%29.08'e ulaşmıştır. Aynı dönemde, tarım dışı sektörlerde istihdam edilen erkek oranı, \%6.09 artış göstermiştir. Tarım sektöründe istihdam edilen kadınların oranı, erkekler ile neredeyse eşit orandadır. Tarım dışı sektörlerde ise kadın istihdam oranı erkek istihdam oranından düşüktür. (Şekil 1).

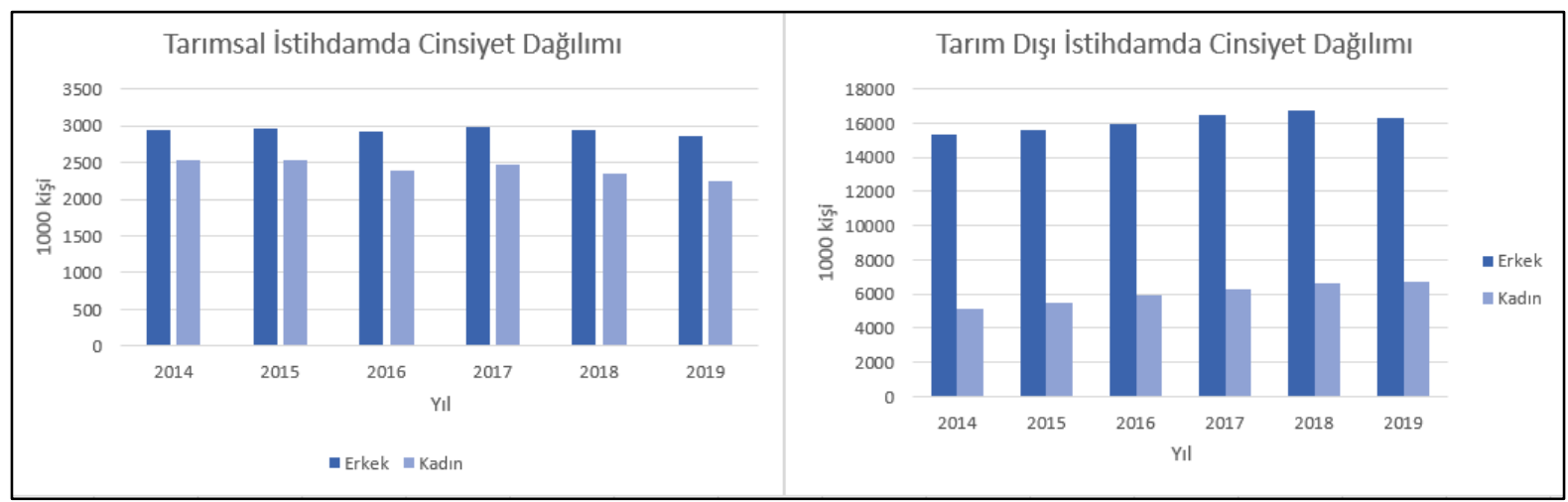

Şekil 1. Türkiye'de tarım ve tarım dışı istihdamda cinsiyet dağılımı (TÜiK, 2020).

Figure 1. The gender distribution of employes in agricultural and non-agricultural employment in Turkey (TURKSTAT, 2020).

Tarımda çalışan kadınların, ağırlıklı olarak ücretsiz aile işçisi konumunda olduğu, tarımda işveren kadın oranının düşük olduğu görülmektedir (Şekil 2.) 




Şekil 2. Türkiye'de tarımsal istihdamda cinsiyetlere göre çalışma şekli (TÜiK, 2020).

Figure 2. The type of work by gender in agricultural employment in Turkey (TURKSTAT, 2020).

Gelişmekte olan ülkelerde, kırsalda yaşayan gençlerin çoğu işsizdir, eğitim fırsatlarından ve temel hizmetlere erişimden yoksundur. Özellikle tarım sektöründeki kırsal iş fırsatları, gençlerin ihtiyaçlarını, isteklerini karşılamamaktadır. Bu durum, dışa doğru yaşanan göç, kırsalda sosyal bozulmanın yanı sıra artan yaşlı bir çiftçi profilinin oluşmasına neden olmaktadır. Bu sorunlar, doğal kaynakların bozulması, iklim değişikliği ve şoklara karşı tarım işletmelerini daha da dirençsiz hale getirmektedir. Ekosistemlerin ve gıda sistemlerinin gelecekteki yöneticileri olarak, ülkelerin gelecekteki krizlere ve şoklara dirençli ve Sürdürülebilir Kalkınma Hedeflerinin gerçekleştirilmesine katkıda bulunan sürdürülebilir uzun vadeli ekonomik kalkınmayı sağlamak için kırsal gençliğe yatırım yapması gerekmektedir (FAO, 2020b).

Türkiye'de kırsal nüfus kent nüfusu ile karşılaştııılığında, sadece göreceli olarak azalmamakta, mutlak olarak da azalmaktadır. Dünya Bankası tahminleri doğrultusunda 2000-2016 döneminde Türkiye'de kırsal nüfus 1.5 milyon kişi azalarak 20.8 milyona gerilemiştir (Anonim, 2018). Antalya, Burdur ve Isparta illerini kapsayan TR61 Bölgesinde de 2012-2019 yılları arasında şehir ve köy nüfus değişimleri incelendiğinde, 2019 yılı köy nüfusunun 2013 nüfusuna göre \%8.34 azaldığı, şehir nüfusunun ise \%15.78 artı̆ğı görülmektedir. Nüfusta, 2013 yılında 2012 yılına göre büyük farklııkların oluşmasındaki temel neden, köy statüsü taşıyan yerleşimlerin yerine mahalle statüsüne geçmiş olmasıdır (Şekil 3).

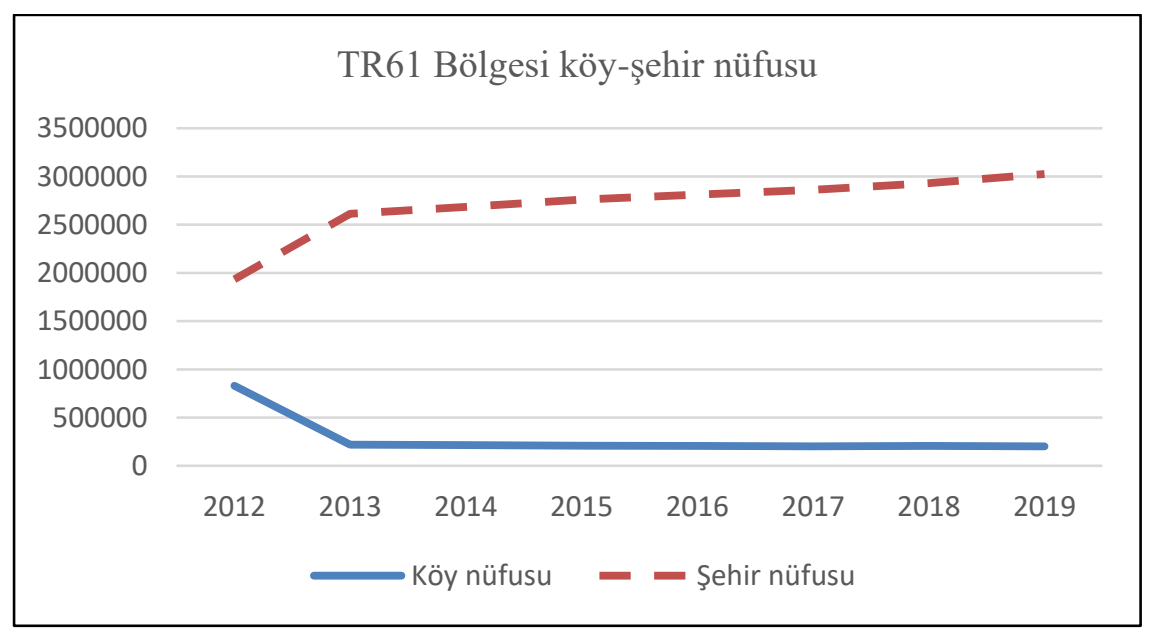

Şekil 3. TR61 Bölgesi köy ve şehir nüfusu değişimi (TÜiK, 2020).

Figure 3. The change of village and city population in TR 61 Region (TURKSTAT, 2020) 
TR61 Bölgesi 2019 yılı köy ve şehir nüfusu yaş grupları açısından incelendiğinde, 20-44 yaş grubundakilerin köy nüfusu içindeki oranının \%26.47, şehir nüfusu içindeki oranının \%39.49 olduğu görülmektedir (Şekil 4).

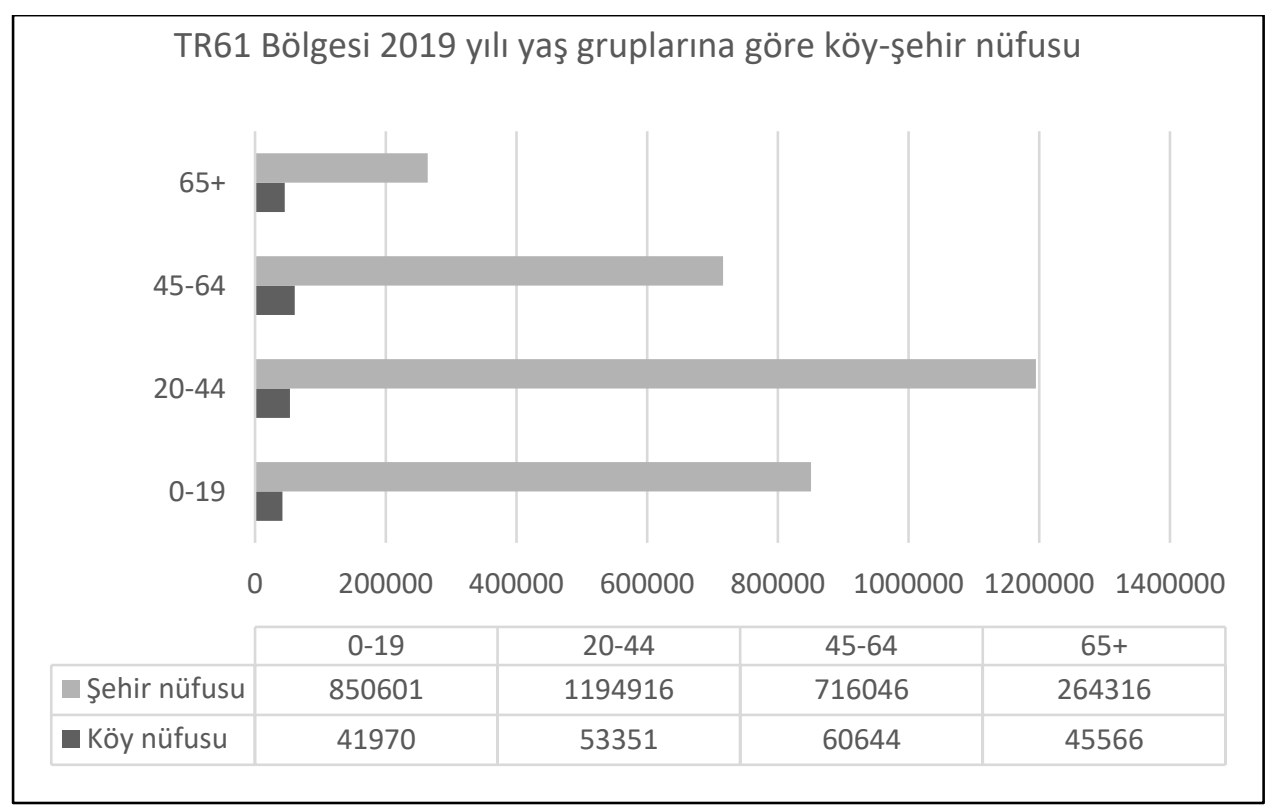

Şekil 4. TR 61 Bölgesi yaş gruplarına göre köy-şehir nüfusu (TÜIK, 2020).

Figure 4. The village and city population by age groups in TR 61 Region (TURKSTAT,2020)

Türkiye'de genç çiftçi tanımlaması; 18-40 yaş aralığında, kırsal alanda ikamet eden/etmek isteyen ve tarımsal faaliyet gösteren/göstermek isteyen gerçek kişiler olarak ifade edilmektedir (TCRG, 2016). 29636 sayılı Resmi Gazetede yayınlanmış olan "2016/8540 sayılı Kırsal Kalkınma Destekleri Kapsamında Genç Çiftçi Projelerinin Desteklenmesine iliş̧kin Karar" genç çiftçilere yönelik oluşturulan ilk yasal düzenlemedir. Bu Karar 'ın amacı, genç çiftçilerin girişimciliğinin desteklenmesi, gelir düzeyinin yükseltilmesi, alternatif gelir kaynaklarının oluşturulması tarımda sürdürülebilirliği sağlayarak genç nüfusun kırsalda istihdamına katkı sağlayan tarımsal üretime yönelik projeleri desteklemektir (TCRG, 2016).

TR61 Bölgesinde; Genç Çiftçi Projelerini Destekleme Programının ilk yılı olan 2016 yılında toplam 15094 hibe başvurusu yapılmış, 534 genç çiftçinin her birine 30000 TL olmak üzere toplam 16 milyon TL hibe desteği verilmiştir. Bu destekleme programında, değerlendirme kriterlerinde kadınlara öncelik tanınmıştır. Hibe desteğinin \%83.1'ini kadın, \%16.9'unu erkek çiftçiler almıştır. Hayvancılık projeleri kapsamında; 292 genç çiftçiye büyükbaş hayvancılık, 69 genç çiftçiye küçükbaş hayvancılık, 45 genç çiftçiye arıcılık, kanatı hayvan yetiştiriciliği alanında hibe verilmiştir. Bitkisel üretim projeleri kapsamında ise toplam 128 genç çiftçiye meyvecilik, bağcılık, üzümsü meyvecilik, örtüaltı yetiştiriciliği, mantarcılık, tıbbi-aromatik bitki, fidan/fide/süs bitkileri alanlarında proje başına 30000 TL hibe ödemesi yapılmıştır. Buna göre; hibe alan projelerin \%55'i büyükbaş hayvan olmak üzere \%76.1'i hayvancılık, \%23.9'u bitkisel projelerden oluşmaktadır. İpekböceği, organik tarım, iyi tarım, coğrafi işaret ürünleri konularında ise hibe desteği alan bulunmamaktadır. 2018 yılında 587 genç çiftçi hibe ödemesi almıştır. Hibe alan projelerin \%61.3'ü hayvancılık, \%38.7'si bitkisel üretim alanlarından oluşmuştur (Kuzgun ve ark., 2018).

Bu çalışmanın amacı TR61 Bölgesindeki genç çiftçilerin ve işletmelerinin özelliklerini tespit edilmesi ve "Genç Çiftçi Projesi" desteğinden yararlanma üzerine etki eden faktörlerin değerlendirilmesidir.

\section{MATERYAL VE METOT}

\section{Materyal}

Araştırmanın ana kitlesini, TR 61 Bölgesinde (Antalya, Burdur, Isparta) "Genç Çiftçi Projesi" desteklerinden yararlanan üreticiler oluşturmaktadır. Çalışmanın materyalini ise Genç Çiftçi Projesi" desteklerinden yararlanan üreticilerden örnekleme yoluyla seçilenler ile karşıt grup olarak aynı sayıda, aynı yaş grubuna sahip kişiler ile yüz yüze yapılan anketlerden elde edilen birincil veriler oluşturmaktadır. Çalışmanın ikincil verilerini ise ulusal ve uluslararası literatürden elde edilen bilgi ve istatistikler oluşturmaktadır. 


\section{Metot}

\section{Örneklemede Kullanilan Metot}

Çalışmanın hedef kitlesini TR 61 Bölgesinde (Antalya, Burdur, Isparta) "Genç Çiftçilerin Desteklenmesi Projesi"'nden yararlanan ve yararlanmayan üreticiler oluşturmaktadır. TR61 Bölgesinde 2016 yılında destekten yararlanan genç çiftçi sayısı 534'dür (Çizelge 1). Örneklemede Basit Tesadüfi Örnekleme yöntemi kullanıımıştır (Yamane, 1967).

$$
n=\frac{N * \sigma^{2}}{(N-1) * D^{2}+\sigma^{2}}
$$

$n$ : Örnek hacmi

$N$ : Populasyondaki birim sayısı

$\sigma:$ Standart sapma

$D=\left(\frac{d}{t}\right)^{2}$

$d$ : Kabul edilebilir hata oranı

$t$ : Çalışmak istenilen güven aralığına ait tablo değeri

Örnek sayısı, \%95 güven aralığında \%10 hata payı ile 72 olarak hesaplanmıştır. Destekten yararlanan 72 üretici, destekten yararlanmayan 72 üretici olmak üzere toplam 144 üretici ile anket yapılmıştır (Çizelge 1).

Çizelge 1. TR61 bölgesi anket yapılan üretici sayıları.

Table 1. The number of producers surveyed in TR61 region.

\begin{tabular}{llllll}
\hline & & Antalya & Burdur & Isparta & Toplam \\
\hline 2016'da Destek Alan Genç Çiftçi Sayısı & Toplam & 213 & 145 & 176 & 534 \\
\hline \multirow{3}{*}{ Anket yapılan örnek sayısı } & Destek alan & 28 & 19 & 25 & 72 \\
& Destek almayan & 28 & 19 & 25 & 72 \\
& Toplam & 56 & 38 & 50 & 144 \\
\hline
\end{tabular}

\section{Verilerin Analizinde Kullanılan Yöntem}

Araştırmada destekten yararlanan ve yaralanmayan üreticilerin ve sahip oldukları işletmelerin özellikleri tanımlayıcı parametreler; minimum, maksimum, ortalama değerler, yüzde oranlar ile ortaya koyulmuştur. Destekten yararlanan ve yararlanmayan üretici grupları arasındaki farklılıkların tespitinde kesikli verilerde Ki-kare testi, normal dağılım göstermeyen sürekli verilerde Mann-Whitney U testi kullanılmıştır (Mann ve Whitney, 1947; Doğan ve ark., 2015; Çobanoğlu ve ark., 2017; Özdamar, 2018).

Destek almayı etkileyen faktörlerin belirlenmesinde İkili Lojistik Regresyon Analizi kullanılmıştır. Bu analiz, eşvaryanslık, normallik ve çok değişkenli normallik şartlarını gerektirmeyen regresyon analizidir (Şenel ve Alatlı, 2014). Lojistik Regresyon Analizi bağımlı değişkenin yapısına göre değişiklik göstermektedir. Çalışmada iki değişkenli bağımlı değişken kullanılması nedeniyle ikili lojistik regresyon analizi kullanılmıştır (Walker ve Duncan, 1967; Tabachnick ve Fidell, 1996; Şenel ve Alatlı, 2014). İkili lojistik regresyon analizinde kullanılan bağımlı değişken, genç çiftçi desteği alma durumudur (destek almayan=0, destek alan=1). Modelde kullanılan sürekli bağımsız değişkenler yaş, deneyim, ailede tarım ile uğraşan birey sayısı, ikamet yerinin şehre uzaklığıdır. Modeldeki kategorik bağımsız değişkenler ise; cinsiyet ( $k a d ı n=0$, erkek=1), medeni durum (bekar=0, evli=1), tarımsal örgüte üyelik durumu ( 1 =hayır, $2=$ evet), sosyal güvenceye sahip olma durumu (evet=1, hayır=2), eğitim düzeyi ( $\leq$ ilkokul=1, ortaokul $\geq=2$ ), tarımsal eğitim durumu (evet=1, hayır=2), tarım dışı gelir (evet=1, hayır=2), tarımsal işletmeye sahip olma durumu (ebeveyn (anne-baba) ile birlikte çalışıp, işletme yönetici ebeveyndir=1, ebeveyn ile birlikte çalışıp, işletme yöneticisi genç çiftçidir $=2$, tarımsal işletmeye sahip=3, çiftçilik yapıyor ama hiçbir tarımsal alet ve makineye sahip değil=4), işletme faaliyet alanı ( $1=$ bitkisel üretim, $2=$ hayvansal üretim, $3=$ bitkisel ve hayvansal üretim). Modelde kullanılan değişkenlerin ilk kategorisi referans kategori olarak alınmıştır. 


\section{BULGULAR VE TARTIŞMA}

Araştırma alanında üreticilerin yaşları 19 ile 40 yaş arasında değişmektedir. Destekten yararlanan üreticilerin ortalama yaşı 28.18 , destekten yararlanmayan üreticilerin ortalama yaşı ise 27.83 'tür. Destek alan üreticilerin ortalama tarımsal deneyimi 7.82 yıl iken destek almayan üreticilerde 8.90 yıldır (Çizelge 2). Genç çiftçi destekleriyle ilgili diğer bölgelerde yapılan çalışmalarda da benzer sonuçlar bunmuştur. Başaranoğlu ve Yılmaz (2020)'ın çalışmalarında ortalama üretici yaşı 28.4'tür. Destek alan üreticilerin ortalama tarımsal deneyimi 7 yıl iken destek almayan üreticilerde 8 yıldır. Altıntaş ve ark. (2020)'nın yaptıkları çalışmada, üreticilerin \%45'inin 6-10 yıl arasında tarımsal deneyime sahip olduğu belirtilmiştir. Çelik (2018) çalışmasında ortalama üretici yaşını 27.24, ortalama tarımsal deneyim süresini ise 6.98 yıl olarak tespit etmiştir.

Anket yapılan üreticilerin tarımla uğraşan aile birey sayısı 1 ile 8 kişi arasında değişmektedir. Yaş, deneyim ve aile birey sayısı üreticilerin destek alma durumuna göre farklıık göstermemektedir ( $p>0.05)$ (Çizelge 2). Anket yapılan üreticilerin belirli yaş aralığında olması, yaş, deneyim ve aile birey sayısı açısından gruplar arasında istatistiki açıdan farklılık olmamasının temel nedeni olarak görülebilir.

Çizelge 2. Üreticilerin yaşı, deneyimi ve ailede tarımla uğraşan birey sayısı.

Table 2. The age and experience of the producers and the number of individuals in the family engaged in agriculture.

\begin{tabular}{|c|c|c|c|c|c|c|c|c|c|}
\hline & \multicolumn{4}{|c|}{ Destek alan } & \multicolumn{4}{|c|}{ Destek almayan } & \multirow{2}{*}{$\begin{array}{l}\text { Mann } \\
\text { Whitney } \\
\text { U testi } \\
\text { Sig. }\end{array}$} \\
\hline & Min. & Max. & Ort. & $\begin{array}{l}\text { St. } \\
\text { Sapma }\end{array}$ & Min. & Max. & Ort. & $\begin{array}{l}\text { St. } \\
\text { Sapma }\end{array}$ & \\
\hline Yaş (yıl) & 19 & 40 & 28.18 & 5.26 & 19 & 40 & 27.83 & 5.56 & 0.655 \\
\hline Deneyim (yıl) & 0 & 17 & 7.82 & 4.62 & 0 & 20 & 8.90 & 5.25 & 0.276 \\
\hline $\begin{array}{l}\text { Ailede tarım ile uğraşan birey } \\
\text { sayısı (kişi) }\end{array}$ & 1 & 6 & 2.42 & 1.07 & 1 & 8 & 2.86 & 1.47 & 0.052 \\
\hline
\end{tabular}

Yaş grupları açısından incelendiğinde, her iki gruptaki üreticilerin \%50'sinin 18-25 yaş aralığında olduğu tespit edilmiştir (Çizelge 3). Doğan ve ark. (2018) çalışmalarında, üreticilerin \%50.40'ının 18-30 yaş, \%49.60'ının ise 31 ve üstünde yaşa sahip olduklarını tespit etmişlerdir. Altıntaş ve ark. (2020) çalışmalarında, üreticilerin \%46.92'sinin 18-25 yaş aralığında olduğunu belirtmişlerdir. Üretici yaş grupları istatistiki açıdan destekleme alma durumlarına göre farklılık göstermemektedir (p: 0.967>0.05) (Çizelge 3).

Çizelge 3. Üretici yaş grupları.

Table 3. The age groups of producers.

\begin{tabular}{llllllll}
\hline \multirow{2}{*}{ Yaş aralığı } & \multicolumn{3}{c}{ Destek alan } & \multicolumn{2}{c}{ Destek almayan } & \multicolumn{3}{c}{ Toplam } & p \\
& Kişi & \% & Kişi & \% & Kişi & \% & (3) \\
\hline $18-25$ & 36 & 50.0 & 36 & 50.0 & 72 & 50.0 & \\
$26-33$ & 26 & 36.1 & 25 & 34.7 & 51 & 35.4 & 0.967 \\
$34-40$ & 10 & 13.9 & 11 & 15.3 & 21 & 14.6 & \\
Toplam & 72 & 100.0 & 72 & 100.0 & 144 & 100.0 & \\
\hline
\end{tabular}

Araştırma alanında destek alan üreticilerin \%36.1'i ilkokul, \%50.0'ı ortaokul düzeyinde eğitim seviyesine sahip iken bu durum destekten yararlanmayan üreticilerde sırasıyla, \%26.4 ve \%33.3'tür. Üniversite mezunu üreticilerin oranının, destekten yararlanmayan üretici grubunda daha yüksek olduğu belirlenmiştir. İstatistiki açıdan gruplar arasında anlamlı bir farklılık bulunmaktadır ( $p: 0.010<0.05$ ) (Çizelge 4). Üniversite mezunu gençlerin, tarım dışı alanlarda çalışma imkanının, üniversite eğitimi almayanlara göre daha yüksek olması, destekten yararlanmayan üreticilerde üniversite mezunu gençlerin oranının yüksek olmasının bir nedeni olabilir.

Çizelge 4. Üreticilerin eğitim durumları.

Table 4. The education level of producers.

\begin{tabular}{|c|c|c|c|c|c|c|c|}
\hline \multirow{2}{*}{ Eğitim durumu } & \multicolumn{2}{|c|}{ Destek alan } & \multicolumn{2}{|c|}{ Destek almayan } & \multicolumn{2}{|c|}{ Toplam } & \multirow[b]{2}{*}{$\mathbf{p}$} \\
\hline & Kişi & $\%$ & Kişi & $\%$ & Kişi & $\%$ & \\
\hline İlkokul & 26 & 36.1 & 19 & 26.4 & 45 & 31.3 & \\
\hline Ortaokul & 36 & 50.0 & 24 & 33.3 & 60 & 41.7 & 0.010 \\
\hline Lise & 7 & 9.7 & 22 & 30.6 & 29 & 20.1 & \\
\hline
\end{tabular}


Çizelge 4. Devamı.

Table 4. Continue.

\begin{tabular}{lccccccc}
\hline \multirow{2}{*}{ Eğitim durumu } & \multicolumn{2}{c}{ Destek alan } & \multicolumn{2}{c}{ Destek almayan } & \multicolumn{2}{c}{ Toplam } & \multirow{2}{*}{ p } \\
& Kişi & \% & Kişi & \% & Kişi & \% & 3.5 \\
\hline Önlisans & 1 & 1.4 & 4 & 5.6 & 5 & 5.5 & 0.010 \\
Üniversite & 2 & 2.8 & 3 & 4.2 & 5 & 3.5 & 100.0 \\
Toplam & 72 & 100.0 & 72 & 100.0 & 144 & \\
\hline
\end{tabular}

Üreticilerin \%20.1'i kadın üretici iken \%79.9'u erkek üreticidir. Destekten yararlanan üreticiler içinde kadın üreticilerin oranı \%83.3'dür (Çizelge 5). Altıntaş ve ark. (2020)'nın yaptıkları çalışmada üreticilerin \%74.23'ünün kadın, \%25.7'sinin erkek olduğunu belirtmişlerdir. Doğan ve ark. (2018) yaptıkları çalışmada ise bu oranlar sırasıyla $\% 60.5$ ve \%39.5'tir. Destekten yararlanan üreticilerde kadın üretici oranının yüksek olmasının, proje başvurusu yapan gençler için, Değerlendirme Kriter Tablosu'nda, puanlamada, kadın üreticilere yönelik pozitif bir ayrımclık yapılarak, ek puan verilmesinden kaynaklandığı düşünülebilir. Destek alma durumuna göre cinsiyet dağılımında istatistiki bir farklılık olduğu belirlenmiştir $(p=0.000<0.05)$ (Çizelge 5).

Araştırma alanında üreticilerin \%21.1'i bekar, \%79.9'u evlidir. Desteklemeden yararlanan üreticilerde bu oran sırasıyla \%1.4 ve \%98.6'dır. Doğan ve ark. (2018)'nın çalışmasında üreticilerin \%82.7'si evli, \%17.3'üu bekardır. Sarı Gedik (2019)'un çalışmasında da benzer sonuçlar verilmiştir. Türkiye'de 2019 yılı evli nüfus oranı \%63'tür (TÜiK, 2020). Ki-kare testine göre çiftçilerin destek alma durumu ile medeni durum arasında anlamlı bir ilişki vardır ( $\mathrm{p}$ : $0.000<0.05$ ) (Çizelge 5).

Üreticilerin eğitim durumu incelendiğinde, \%31.2'sinin en fazla ilkokul eğitimine sahip olduğu, \%68.8'inin ise ortaokul ve üstü eğitim düzeyine sahip olduğu belirlenmiştir. Destek alan grupta bu oran sırasıyla \%36.1 ve \%63.9'dur. Ki-kare testine göre çiftçilerin destek alma durumu ile eğitim durumu arasında anlamlı bir ilişki yoktur (p: 0.208> 0.05) (Çizelge 5).

Üreticilerin \%69.4'ünün tarımsal örgüte üyeliği bulunurken, \%30.6'sının herhangi bir örgüte üye olmadığı tespit edilmiştir. Desteklemeden yararlanan üreticilerde bu oran sırasıyla \%88.9 ve \%11.1'dir (Çizelge 5). Altıntaş ve ark. (2020) destek alan üreticilerin \%39.17'sinin tarımsal örgüte üye olduğunu, destek almayanlar da ise bu oranın \%18.57 olduğunu belirtmişlerdir. Ki-kare testine göre, çiftçilerin destek alma durumu ile örgüt üyeliği arasında anlamlı bir ilişki vardır ( $\mathrm{p:} 0.000<0.05)$ (Çizelge 5).

Işletme faaliyet türü açısından destek alan ve almayan grup incelendiğinde, gruplar arasında istatistiki olarak anlamlı bir fark olmadığı tespit edilmiştir $(p=0.604>0.05)$. Her iki grupta da bitkisel ve hayvansal üretimi birlikte yapanların oranı \%59.7 ile en yüksek orana sahiptir (Çizelge 5). Altıntaş ve ark. (2020), destek alanların \%57.50'sinin bitkisel ve hayvansal üretimi birlikte yaptığını, destek almayanlarda ise bu oranın \%42.14 olduğunu belirtmişlerdir.

Üreticilerin tarım dışı gelire sahip olma durumları incelendiğinde, \%37.5'i tarım dışı gelire sahipken \%62.5'i tarım dışı gelire sahip değildir. Destekten yararlanan üreticilerde bu oranlar sırasıyla \%26.4 ve \%73.6'dır. Destekten yararlanmayan üreticilerde tarım dışı gelire sahip olanların oranının (\%48.6) daha yüksek olduğu görülmektedir (Çizelge 5). Altıntaş ve ark. (2020) da benzer şekilde destek alanların \%91.67'sinin tarım dışı gelirinin bulunmadığını, bu oranın destek almayan grupta \%77.14 olduğunu belirtmişlerdir. Doğan ve ark. (2018) ise üreticilerin \%35.9'unun tarım dışı gelire sahip olduğunu belirlemiştir. Gruplar arasında, üreticilerin tarım dışı gelire sahip olma durumu istatistiki açıdan farklılık göstermektedir (p: $0.006<0.05$ ) (Çizelge 5).

Tarımsal işletmeye sahip olma durumları açısından incelendiğinde, destek alan üreticilerin \%56.9'unun tarımsal işletmenin sahibi olduğu, destek almayan üreticilerin ise \%52.8'inin ebeveynleri ile birlikte çalıştıkları ve işletme yöneticisinin ebeveynleri olduğu belirlenmiştir (Çizelge 5). Altıntaş ve ark. (2020) destek alanların \%64.17'sinin işletme yöneticisinin ebeveynleri olduğunu, destek almayanlar da ise bu oranın $\% 55.00$ olduğunu belirtmişlerdir. Gruplar arasında, üreticilerin işletmeye sahip olma durumu, istatistiki açıdan anlamlı bir farklılık göstermektedir $(p=0.008<0.05)$ (Çizelge 5).

Çizelge 5. Destekten yararlanma durumuna göre üretici ve işletme özellikleri.

Table 5. The characteristics of producers and agricultural holdings.

\begin{tabular}{|c|c|c|c|c|c|c|c|c|}
\hline & & \multicolumn{2}{|c|}{ Destek alan } & \multicolumn{2}{|c|}{ Destek almayan } & \multicolumn{2}{|c|}{ Toplam } & \multirow[b]{2}{*}{$\mathbf{p}$} \\
\hline & & Adet & $\%$ & Adet & $\%$ & Adet & $\%$ & \\
\hline \multirow{3}{*}{ Cinsiyet } & Kadın & 60 & 83.3 & 19 & 26.4 & 79 & 20,1 & \\
\hline & Erkek & 12 & 16.7 & 53 & 73.6 & 65 & 79,9 & $0.000 *$ \\
\hline & Toplam & 72 & 100.0 & 72 & 100.0 & 144 & 100,0 & \\
\hline
\end{tabular}


Çizelge 5. Devamı.

Table 5. Continue.

\begin{tabular}{|c|c|c|c|c|c|c|c|c|}
\hline & & \multicolumn{2}{|c|}{ Destek alan } & \multicolumn{2}{|c|}{ Destek almayan } & \multicolumn{2}{|c|}{ Toplam } & \multirow{2}{*}{$\mathbf{p}$} \\
\hline & & Adet & $\%$ & Adet & $\%$ & Adet & $\%$ & \\
\hline \multirow{3}{*}{$\begin{array}{l}\text { Medeni } \\
\text { durum }\end{array}$} & Bekar & 1 & 1.4 & 28 & 38.9 & 29 & 21,1 & \multirow{3}{*}{$0.000^{*}$} \\
\hline & Evli & 71 & 98.6 & 44 & 61.1 & 115 & 79.9 & \\
\hline & Toplam & 72 & 100.0 & 72 & 100.0 & 144 & 100.0 & \\
\hline \multirow{3}{*}{$\begin{array}{l}\text { Eğitim } \\
\text { durumu }\end{array}$} & En fazla ilkokul & 26 & 36,1 & 19 & 26,4 & 45 & 31,2 & \multirow{3}{*}{0.208} \\
\hline & Ortaokul ve sonrası & 46 & 63,9 & 53 & 73,6 & 99 & 68,8 & \\
\hline & Toplam & 72 & 100.0 & 72 & 100.0 & 144 & 100.0 & \\
\hline \multirow{3}{*}{$\begin{array}{l}\text { Örgüt } \\
\text { üyeliği }\end{array}$} & Üye & 64 & 88.9 & 36 & 50.0 & 100 & 69.4 & \multirow{3}{*}{$0.000^{*}$} \\
\hline & Üye değil & 8 & 11.1 & 36 & 50.0 & 44 & 30.6 & \\
\hline & Toplam & 72 & 100.0 & 72 & 100.0 & 144 & 100.0 & \\
\hline \multirow{3}{*}{$\begin{array}{l}\text { Tarım dışı } \\
\text { gelir varlığı }\end{array}$} & Var & 19 & 26.4 & 35 & 48.6 & 54 & 37.5 & \multirow{3}{*}{$0.006^{*}$} \\
\hline & Yok & 53 & 73.6 & 37 & 51.4 & 90 & 62.5 & \\
\hline & Toplam & 72 & 100.0 & 72 & 100.0 & 144 & 100.0 & \\
\hline \multirow{4}{*}{$\begin{array}{l}\text { İşletme } \\
\text { faaliyet } \\
\text { türü }\end{array}$} & Bitkisel üretim & 22 & 30.6 & 25 & 34.7 & 47 & 32.6 & \multirow{4}{*}{0.604} \\
\hline & Hayvansal üretim & 7 & 9.7 & 4 & 5.6 & 11 & 7.6 & \\
\hline & Karma üretim & 43 & 59.7 & 43 & 59.7 & 86 & 59.7 & \\
\hline & Toplam & 72 & 100.0 & 72 & 100.0 & 72 & 100.0 & \\
\hline \multirow{5}{*}{$\begin{array}{l}\text { Tarımsal } \\
\text { işletmeye } \\
\text { sahip olma } \\
\text { durumu }\end{array}$} & $\begin{array}{l}\text { Ebeveyn ile birlikte çalışıp, } \\
\text { işletme yöneticisi ebeveyndir. }\end{array}$ & 18 & 25 & 38 & 52,8 & 56 & 38,9 & \multirow{5}{*}{$0.008^{*}$} \\
\hline & $\begin{array}{l}\text { Ebeveyn ile birlikte çalışıp, } \\
\text { işletme yöneticisi kendisidir. }\end{array}$ & 11 & 15,3 & 7 & 9,7 & 18 & 12,5 & \\
\hline & $\begin{array}{l}\text { Tarımsal işletme kendisinin. } \\
\text { Ciftcilik yapıyor ancak hicbir }\end{array}$ & 41 & 56,9 & 26 & 36,1 & 67 & 46,5 & \\
\hline & $\begin{array}{l}\text { tarımsal alet ve makineye sahip } \\
\text { değil. }\end{array}$ & 2 & 2,8 & 1 & 1,4 & 3 & 2,1 & \\
\hline & Toplam & 72 & 100 & 72 & 100 & 144 & 100 & \\
\hline
\end{tabular}

Araştırma alanındaki işletmelerin arazi varlığı incelendiğinde, destekten yararlanan işletmelerin ortalama arazi büyüklüğü 44.78 da, işlenen arazi büyüklüğü ise 38.60 dekardır. Destekten yararlanmayan işletmelerde ise sırasıyla 48.52 da ve 45.38 da olduğu tespit edilmiştir. Destek alan üreticilerin ortak işlenen arazisi bulunmazken, destek almayan üreticilerin, ortalama 5.17 da araziyi ortak işlediği belirlenmiştir. Tarımsal sürdürülebilirliği sağlamaya çalışan bu destekleme programında, bağımsız olarak faaliyet gösteren işletmelerin hedeflenmesi beklenen bir sonuçtur. Altıntaş ve ark. (2020), ortalama arazi varlığının destekten yararlanan işletmelerde 34.48 da, destekten yararlanmayan işletmelerde ise 38.29 da olduğunu belirtmişlerdir. Gruplar arasında farklılıklar incelendiğinde, ortak işlenen arazi açısından istatistiki olarak bir farklılık olduğu tespit edilmiştir (p: 0.043 <0.05) (Çizelge 6).

Çizelge 6. İşletme arazi varlığı, mülkiyet durumu, sulanma durumu ve parsel sayısı.

Table 6.The land size, the ownership status, the amount of irrigated land and the numbre of parcels.

\begin{tabular}{|c|c|c|c|c|c|c|c|c|c|}
\hline & \multicolumn{4}{|c|}{ Destek alan } & \multicolumn{4}{|c|}{ Destek almayan } & \multirow{2}{*}{$\begin{array}{l}\text { Mann } \\
\text { Whitney } \\
\text { U testi } \\
\text { Sig. }\end{array}$} \\
\hline & Min. & Max. & Ort. & $\begin{array}{l}\text { St. } \\
\text { Spm. }\end{array}$ & Min. & Max. & Ort. & $\begin{array}{l}\text { St. } \\
\text { Spm. }\end{array}$ & \\
\hline Toplam arazi (da) & 0 & 300 & 44.78 & 61.58 & 0 & 335 & 48.52 & 65.95 & 0.558 \\
\hline İşlenen arazi (da) & 0 & 300 & 38.60 & 61.38 & 0 & 335 & 45.38 & 63.51 & 0.160 \\
\hline Aile arazisi (da) & 0 & 180 & 22.44 & 38.54 & 0 & 200 & 20.50 & 34.39 & 0.725 \\
\hline Mülk arazi (da) & 0 & 70 & 6.06 & 14.15 & 0 & 75 & 5.16 & 11.69 & 0.893 \\
\hline Kiralanan arazi (da) & 0 & 230 & 16.00 & 41.09 & 0 & 230 & 17.69 & 40.43 & 0.836 \\
\hline Ortak işlenen arazi (da) & 0 & 0 & 0 & 0 & 0 & 202 & 5.17 & 27.01 & $0.043^{*}$ \\
\hline Sulanan arazi (da) & 0 & 194 & 21.24 & 38.09 & 0 & 150 & 24.41 & 37.93 & 0.310 \\
\hline Parsel sayısı (adet) & 0 & 25 & 5.64 & 6.31 & 0 & 32 & 5.74 & 5.51 & 0.268 \\
\hline $\begin{array}{l}\text { İkamet yerinin şehre uzaklığı } \\
(\mathrm{km})\end{array}$ & 1 & 69 & 16.65 & 10.94 & 1 & 35 & 13.57 &, 43 & 0.155 \\
\hline
\end{tabular}


Destek alan üreticilerin \%97.2'sinin ailesi çiftçilikle uğraşırken destek almayanlarda bu oranın \%93.1 olduğu belirlenmiştir (Çizelge 7). Doğan ve ark. (2018), üreticilerin \%79.4'ünün ailesinin çiftçilik ile uğraştığını tespit etmişlerdir.

Çizelge 7. Üretici ailelerinin tarımsal faaliyet yapma durumu.

Table 7. The producers family working in agriculture.

\begin{tabular}{|c|c|c|c|c|c|c|c|}
\hline \multirow{2}{*}{$\begin{array}{l}\text { Çiftçilik yapma } \\
\text { durumu }\end{array}$} & \multicolumn{2}{|c|}{ Destek alan } & \multicolumn{2}{|c|}{ Destek almayan } & \multicolumn{2}{|c|}{ Toplam } & \multirow{2}{*}{$\mathbf{P}$} \\
\hline & Adet & $\%$ & Adet & $\%$ & Adet & $\%$ & \\
\hline Yapıyor & 70 & 97.2 & 67 & 93.1 & 137 & 95.1 & \\
\hline Yapmıyor & 2 & 2.8 & 5 & 6.9 & 7 & 4.9 & 0.245 \\
\hline Toplam & 72 & 100.0 & 72 & 100.0 & 144 & 100.0 & \\
\hline
\end{tabular}

Görüşülen üreticilerin "Genç Çiftçi Projelerini Destekleme Programı" öncesinde de tarımsal faaliyette bulunma durumları incelendiğinde, her iki grupta da üreticilerin \%98.6'sının önceden de çiftçilik yaptığı tespit edilmiştir (Çizelge 8). Doğan ve ark. (2018), destekten yararlanan üreticilerin \%82'sinin hali hazırda çiftçilik yaptıklarını belirtmiş̧lerdir.

Çizelge 8. Üreticilerin çiftçilik yapma durumu.

Table 8. The producers working in agriculture..

\begin{tabular}{|c|c|c|c|c|c|c|c|}
\hline & \multicolumn{2}{|c|}{ Destek alan } & \multicolumn{2}{|c|}{ Destek almayan } & \multicolumn{2}{|c|}{ Toplam } & \multirow{2}{*}{$\mathbf{p}$} \\
\hline & Adet & $\%$ & Adet & $\%$ & Adet & $\%$ & \\
\hline Önceden de çiftçi & 71 & 98.6 & 71 & 98.6 & 142 & 98.6 & \\
\hline Yeni başlayacak & 1 & 1.4 & 1 & 1.4 & 2 & 1.4 & 1.0 \\
\hline Toplam & 72 & 100.0 & 72 & 100.0 & 144 & 100.0 & \\
\hline
\end{tabular}

Üreticilerin "Genç Çiftçi Projelerini Destekleme Programı"ndan haberdar olma durumları incelendiğinde destekten yararlanmayan üreticilerin \%95.8'inin destekten haberdar olduğu belirlenmiştir. Gruplar arasında istatistiki açıdan anlamlı bir farklılık bulunmamıştır $(p=0.080>0.05)$ (Çizelge 9).

Çizelge 9. Üreticilerin desteklemeden haberdar olma durumları.

Table 9. The producers' status of being aware of the support.

\begin{tabular}{|c|c|c|c|c|c|c|c|}
\hline & \multicolumn{2}{|c|}{ Destek alan } & \multicolumn{2}{|c|}{ Destek almayan } & \multicolumn{2}{|c|}{ Toplam } & \multirow[b]{2}{*}{$\mathbf{p}$} \\
\hline & Adet & $\%$ & Adet & $\%$ & Adet & $\%$ & \\
\hline Evet & 72 & 100.0 & 69 & 95.8 & 141 & 97.9 & \\
\hline Hayır & 0 & 0.0 & 3 & 4.2 & 3 & 2.1 & 0.080 \\
\hline Toplam & 72 & 100.0 & 72 & 100.0 & 144 & 100.0 & \\
\hline
\end{tabular}

Kurulan ikili lojistik regresyon modelinde, model katsayıları anlamlıdır. Bağımlı değişken ile bağımsız değişkenler arasında ilişki bulunmaktadır $(X 2=115.762, p=0.000)$. Hosmer and Lemoshow $X^{2}=8.804, p=0.359$ olup model uyum iyiliği şartını sağlamaktadır. Modelde kullanılan bağımsız değişkenlerin genç çiftçi desteğinden yararlanma durumunu açıklama oranları; Cox and Snell istatistğine göre \%55.1, Nagelkerke $R^{2}$ istatistiğine göre \%73.5'dir (Çizelge 10). Model ile Genç Çiftçi Desteklerinden yararlanmayanların \%87.5'i, yararlananların ise \%90.3'ü doğru tahmin edilmiştir (Çizelge 10).

Modelde yer alan bağımsız değişkenlerden üreticilerin yaşı, tarımsal deneyimi, eğitim durumu, tarımsal eğitim alma durumu, sosyal güvenceye sahip olma durumu, tarımsal işletmeye sahip olma durumu, işletme faaliyet alanı, ailede tarım yapan birey sayısı ve ikamet yerinin şehre uzaklığı, üreticilerin genç çiftçi desteklerinden yararlanmaları üzerinde istatistiksel olarak bir etki yaratmamaktadır. Buna karşılık üreticilerin cinsiyeti, medeni durumu, tarımsal örgüte üye olma durumu ve tarım dışı gelir sahipliğinin genç çiftçi desteklerinden yararlanmada etkili olduğu belirlenmiştir (Çizelge 10).

Kadın üreticilerin genç çifţi desteğinden yararlanma olasılığı erkek üreticilere göre 0.021 kat fazladır $(p=0,000)$ (Çizelge 10). Kan ve ark. (2019), kadınların destekten faydalanma oranının yüksek olduğunu, Doğan ve ark. (2018) ise erkek bireylerde destekten faydalanma olasılığının 0.257 kat arttığını belirlemişlerdir.

Evli olan üreticilerin bekar üreticilere göre genç çiftçi desteğinden yararlanma olasılıkları 14 kat daha fazladır $(p=0,049)$ (Çizelge 10). Bu sonuç, Doğan ve ark. (2018), Kan ve ark. (2019), Altıntaş ve ark. (2020) ile paralellik göstermektedir. Bu durum, daha önce yukarıda da bahsedildiği gibi Değerlendirme Kriter Tablosu'nda puanlamada, kadın ve medeni durumu evli olan üreticilere yönelik pozitif bir ayrımcılık yapılması ile açıklanabilir. 
Tarım dışı geliri olmayan üreticilerin tarım dışı geliri olan üreticilere göre destekten yararlanma olasılığı 11 kat daha fazladır $(p=0,001)$ (Çizelge 10). Altıntaş ve ark. (2020)'nın sonuçları bu çalışma ile paralellik gösterirken, Doğan ve ark. (2018), tarım dışı geliri destekten faydalanma üzerinde etkili bulmamışlardır.

Tarımsal örgüte üyeliği olan üreticilerin genç çiftçi desteğinden yararlanma olasılığı, üyeliği olmayan üreticilere göre 23.4 kat daha fazladır ( $p=0.000$ ) (Çizelge 10). Altıntaş ve ark. (2020), tarımsal örgüte üye olma durumunun pozitif yönde etkili olduğunu belirtmişlerdir.

Çizelge 10. Genç çiftçi desteklerinden yararlanmayı etkileyen faktörlerin belirlenmesine yönelik logit model tahminleri. Table 1. Logit model estimates to determine the factors affecting the utilization of young farmer support.

\begin{tabular}{|c|c|c|c|c|c|}
\hline & Katsayı & Std. Hata & Wald & $\mathbf{p}$ & Olasılık Oranı \\
\hline Sabit & -1.012 & 3.223 & 0.099 & 0.754 & 0.363 \\
\hline Yaş & -0.035 & 0.089 & 0.154 & 0.695 & 0.966 \\
\hline Cinsiyet & -3.861 & 0.838 & 21.215 & 0.000 & 0.021 \\
\hline Medeni durum & 2.644 & 1.341 & 3.891 & 0.049 & 14.075 \\
\hline Tarımsal deneyim & -0.115 & 0.079 & 2.125 & 0.145 & 0.891 \\
\hline Eğitim & -0.502 & 0.782 & 0.412 & 0.521 & 0.605 \\
\hline $\begin{array}{l}\text { Tarımsal üretim konularında eğitime } \\
\text { katııım }\end{array}$ & -0.662 & 0.735 & 0.813 & 0.367 & 0.516 \\
\hline Sosyal güvence varlığı & -1.117 & 0.684 & 2.665 & 0.103 & 0.327 \\
\hline Tarımsal örgüte üyelik & 3.153 & 0.876 & 12.948 & 0.000 & 23.404 \\
\hline Tarım dışı gelire sahip olma & 2.418 & 0.755 & 10.253 & 0.001 & 11.228 \\
\hline Tarımsal işletmeye sahip olma & & & 1.036 & 0.792 & \\
\hline $\begin{array}{l}\text { Ebeveyn (anne-baba) ile birlikte çalışıp, } \\
\text { işletme yöneticisi genç çiftçidir }\end{array}$ & -0.863 & 1.105 & 0.610 & 0.435 & 0.422 \\
\hline Tarımsal işletme kendisinin & -0.107 & 0.854 & 0.016 & 0.900 & 0.898 \\
\hline $\begin{array}{l}\text { Çiftçilik yapıyor ancak hiçbir tarımsal alet } \\
\text { ve makineye sahip değil. }\end{array}$ & 1.397 & 3.186 & 0.192 & 0.661 & 4.045 \\
\hline İşletme faaliyet alanı & & & 2.365 & 0.306 & \\
\hline Hayvansal üretim & 2.055 & 1.366 & 2.264 & 0.132 & 7.809 \\
\hline Bitkisel ve hayvansal üretim & 0.573 & 0.684 & 0.700 & 0.403 & 1.773 \\
\hline Ailede tarımla uğraşan birey sayısı & -0.522 & 0.335 & 2.424 & 0.119 & 0.593 \\
\hline İkamet edilen yerin şehre uzaklığı & 0.047 & 0.036 & 1.742 & 0.187 & 1.048 \\
\hline
\end{tabular}

Nagelkerke R Square $=0.738 \quad$ Cox \& Snell $X^{2}=0.553$

-2 Log likelihood $=83.598$ a

$\mathrm{X} 2=3.915 \quad \mathrm{p}=0.865$ (Hosmer and Lemeshow Test)

$\mathrm{X} 2=116.028 \quad \mathrm{p}=0.000$ (Omnibus Test)

Doğan ve ark. (2018), cinsiyet, medeni durum, ailenin çiftçilikle uğraşma durumu, tarım dışı geliri olma durumu, ikamet edilen yerin nüfusu, sosyal güvenceye sahip olma durumu ve mülk arazi sahipliğinin genç çiftçi desteklerinden faydalanma üzerinde etkili faktörler olduğunu tespit etmişlerdir. Kan ve ark. (2019) ise engelli, şehit yakını ya da gazi olan, tarımsal eğitime sahip, 18-30 yaş aralığında, evli, kadın ve 100 ve altı nüfusa sahip yerleşim yerlerinde ikamet eden ve $10000 \mathrm{TL}$ ve altı gelire sahip işletmelerdeki üreticilerin destekten daha fazla oranda yararlandıklarını belirtmişlerdir. Altıntaş ve ark. (2020), cinsiyet, ikamet edilenin bölgenin şehir merkezine uzaklığı ve tarımsal konularda eğitim alma durumunun desteklemeden yararlanma üzerine etkili olduğunu belirtmişlerdir.

\section{SONUÇ}

Tarım ve Orman Bakanlığı, 2016 yılında genç çiftçilerin girişimciliğinin desteklenmesi, gelir düzeyinin yükseltilmesi, alternatif gelir kaynaklarının oluşturulması, tarımda sürdürülebilirliği sağlayarak genç nüfusun kırsalda istihdamına katkı sağlanması amacıyla "Genç Çiftçi Projeleri" desteklemelerini uygulamaya koymuştur. Antalya, Burdur, Isparta illerini kapsayan TR61 Bölgesinde 2016 yllında 534 genç çiftçiye 16 milyon TL hibe verilmiştir.

TR61 Bölgesinde genç çiftçi projesi desteklerinden yararlananların yaş ortalaması 28'dir. TR 61 Bölgesinde 2044 yaş aralığında olan nüfusun, kırsal nüfus içindeki payı düşüş göstermektedir. Destekten yararlananların 28 yaş ortalamasında olması, "Genç Çiftçi Projesi" desteğinin kırsaldaki genç nüfus göçünü azaltma açısından etkili bir araç olarak kullanılabileceğinin bir göstergesidir. Türkiye'de tarımda ücretsiz aile işçisi olarak çalışanların çoğunluğunu kadınlar oluşturmaktadır. Araştırma alanında kadınların genç çiftçi projesi desteğinden daha fazla yararlandığı belirlenmiştir. Bu şekilde, TR61 Bölgesinde kadınların işletmede ücretsiz aile işçiliğinden çıkmasına, 
kadınların işletmede karar verme süreçlerine dahil olmasına ve kadın istihdamının artııılmasına destek olunmaktadır. Destekten yararlanan genç çiftçilerde tarım dışı gelire sahip olanların oranı düşüktür. Bu da, tarımsal faaliyetleri temel geçim kaynağı olan üreticilere öncelik verildiğinin bir göstergesidir.

TR61 Bölgesinde genç çiftçi projesi desteklerinden yararlanmayı etkileyen faktörler incelendiğinde, kadın üreticilerin erkek üreticilere, evli üreticilerin bekar üreticilere, tarım dışı gelire sahip olmayan üreticilerin tarım dışı gelire sahip olan üreticilere, tarımsal örgüte üye olan üreticilerin tarımsal örgüte üye olmayan üreticilere göre destekten yararlanma olasılığının yüksek olduğu belirlenmiştir.

İnsanoğlunun varlığının devamlılığı için besin arzının sürdürülebilirliğinin sağlanması gerekmektedir. Artan nüfus, artan kişi başı tüketim miktarı ve iklim değişikliği başta olmak üzere doğal kaynaklar üzerindeki baskı, besin arzını sağlayan tarım sektörünün önemini her geçen gün daha da artırmaktadır. Kırsal alanda yaşayan halkın temel geçim kaynağını oluşturan tarımsal faaliyetlerin devamlıı̆ını sağlamak da bu açıdan önem arz etmektedir. Sadece Türkiye'de değil küresel olarak da kırdan kente göç tarımsal faaliyetlerin devamlıı̆ını etkileyen bir diğer önemli faktördür. Kırsalda bulunan genç nüfus eğitim ve iş olanaklarının yetersizliği başta olmak üzere pek çok sebeple kentlere göç etmektedir. Tarımsal faaliyetler ile uğraşan genç nüfus oranındaki düşüş, tarımın sürdürülebildiğini olumsuz yönde etkilemektedir. Tarım ve Orman Bakanlığı tarafından genç çiftçilere verilen desteklemeler büyük önem arz etmektedir. Genç çiftçi destekleri alana özel çeşitlendirilerek devamlılığı sağlanmalıdır. Genç çiftçi desteğinden yararlanmış olan üreticilerin yaptıkları faaliyetleri geliştirmelerine yönelik eğitimler, genç çiftçileri bir araya getirebilecek farklı örgütlenme modellerinin geliştirilmesi, pazara ulaşmada kolaylık sağlayacak öncelikler, dijital pazarlama yöntemlerinin yaygınlaştıııması gibi ek destekler de verilen genç çiftçi desteğinin etkinliğini artıracaktır.

\section{ÇIKAR ÇATIŞMASI}

Yazarlar arasında herhangi bir çıkar çatışması bulunmamaktadır.

\section{YAZAR KATKISI}

Tuba BEŞEN, literatür taraması, anket çalışması, makalenin yazılması, metodolojinin uygulanması. Betül SAYIN, literatür taraması, anket çalışması, makalenin yazılması, metodolojinin uygulanması. Musa KUZGUN, literatür taraması, anket çalışması, makalenin yazııması, metodolojinin uygulanması. Dilek KARAMÜRSEL, anket çalışması, makalenin yazııması, Mehmet Ali ÇELiKYURT anket çalışması, makalenin yazılması, Meltem EMRE anket çalışması, makalenin yazılması, Fatma Pınar ÖZTÜRK anket çalışması, makalenin yazılması, Şerife Gülden YILMAZ anket çalışması, Duygu BíROL metodolojinin geliştirilmesi.

\section{TEŞEKKÜR}

Bu çalışma Tarım ve Orman Bakanlığı, Tarımsal Araştırmalara ve Politikalar Genel Müdürlüğü tarafından desteklenen TAGEM/TEPD/17/G/A08/P03/001-007 numaralı "TR61 Bölgesinde Genç Çiftçi Desteklemelerine Kriter Olabilecek Parametrelerin ve Gençlerin Tarımda Kalma Eğilimlerinin Belirlenmesi" Projesi kapsamında gerçekleştirilmiştir.

\section{KAYNAKLAR}

Altıntaş, G., Altıntaş, A., Oruç, E., Kızılaslan, H., Çakmak, E., \& Birol, D. (2020). Genç çiftçi proje desteğinden yararlanmayı etkileyen faktörler; TR-83 bölgesi örneği. Turkish Journal of Agricultural Engineering Research (Turkager), 1(1), $152-168$.

Anonim. (2018). On birinci kalkınma planı (2019-2023), Kırsal Kalkınma Özeli İhtisas Komisyonu Raporu, Türkiye Cumhuriyeti, Kalkınma Bakanlığı, $\quad$ Ankara. $\quad$ (https://www.sbb.gov.tr/wpcontent/uploads/2020/04/KirsalKalkinmaOzellhtisasKomisyonuRaporu.pdf) Erişim tarihi: 05 Ekim 2020.

Başaranoğlu, C., \& Yılmaz, H. (2020). Genç Çiftçilerin çiftçilik yapma eğilimlerinin ve çifçilik özelliklerinin belirlenmesi: Isparta ili örneği. Tarım Ekonomisi Dergisi, 26(1), 19-28.

Çelik, N. (2018). Tarımda kadın girişimciliği ve genç çiftçi projesi: Kahramanmaraş ili örneği. Yüksek Lisans Tezi, Kahramanmaraş Sütçü İmam Üniversitesi, Fen Bilimleri Enstitüsü Kahramanmaraş, Türkiye.

Çobanoğlu, F., Tunalığlu, R., Yılmaz, H. İ., Bozkıran, S., Nalbantoğlu, A., \& Yıldız, H. (2017). Kırsal kalkınma yatırımlarının desteklenmesi programının değerlendirilmesi: Bursa ili örneği. Tekirdağ Ziraat Fakültesi Dergisi, 5(1), 16-27.

DB. (2020). Agriculture and food. https://www.worldbank.org/en/topic/agriculture/overview, Erişim tarihi: 05 Ekim 2020. 
Doğan, G., Yavuz Keskin, S., Aktürk Hayat, E., Karataş, E., \& Bircan, R. (2015). Sinop ilinde organik balık bilincinin belirlenmesi. Yüzün Yıl Üniversitesi Tarım Bilimleri Dergisi, 25(2), 174-179.

Doğan, H. G., Kan, A., Kan, M., Tosun, F., Uçum, İ., Solmaz, C., \& Birol, D. (2018). Türkiye'de genç çiftçi proje desteğinden yararlanma düzeyini etkileyen faktörlerin değerlendirilmesi. Tür Tarım- Gıda Bilim ve Teknoloji Dergisi, 6(11), $1599-1606$.

FAO. (2020a). The state of food security and nutrition in the world, Transforming food systems for affordable healthy diets. Food and Agriculture Organization of the United Nations, Rome, 2020. Erişim tarihi: 19 Ekim 2020.

FAO. (2020b). Committee on agriculture, twenty-seventh session, rural youth action plan. COAG/2020/12. http://www.fao.org/3/nd385en/nd385en.pdf. Erişim tarihi: 19 Ekim 2020.

Kan, M., Tosun, F., Kan, A., Gokhan Dogan, H., Ucum, I., \& Solmaz, C. (2019). Young farmers in agriculture sector of Turkey: Young farmers support program. Jounal of Agriculture, Science and Technology, 21, 15-26.

Kuzgun, M., Sayın, B., Karamürsel, D., Çelikyurt, M. A., Emre, M., Beşen, T., Öztürk, F. P., Yılmaz, Ş. G., \& Birol, D. (2018). TR61 Bölgesinde Genç Çiftçi Desteklemelerine Kriter Olabilecek Parametrelerin Ve Gençlerin Tarımda Kalma Eğilimlerinin Belirlenmesi. Projesi Sonuç Raporu, Proje No: TAGEM/TEPD/17/G/A08/P03/001-007, Batı Akdeniz Tarımsal Araştırma Enstitüsü Müdürlüğü, Antalya.

Mann, H. B., \& Whitney, D. R. (1947). On a test of whether one of two random variables is stochastically larger than the other, Annals of Mathematical Statistics.

Özdamar, K. (2018). Paket Programlar ile Istatistiksel Veri Analizi. Nisan Kitapevi, Eskişehir.

Sarı Gedik, D. (2019). Kırsal kalkınmada genç çiftçi projesi: Tekirdağ ili örneği. Yüksek Lisans Tezi, Tekirdağ Namık Kemal Üniversitesi, Fen Bilimleri Enstitüsü, Tekirdağ, Türkiye.

TÜiK. (2020). Veri portalı. http://www.tuik.gov.tr/PreTablo.do?alt_id=1068. Erişim tarihi: 15 Ekim 2020.

Walker, S. H., \& Duncan, D. B. (1967). Estimation of probability of an event as a function of several independent variables. Biometrika, 54(1), 167-179.

Tabachnick, B. G., \& Fidell, L. S. (1996). Using Multivariate Statistics (3rd ed.). Newyork, USA: Harper Colins.

Şenel, S., \& Alatlı, B. (2014). Lojistik regresyon analizinin kullanıldığı makaleler üzerine bir inceleme. Eğitimde ve Psikolojide Ölçme ve Değerlendirme Dergisi, 5(1), 35-52.

TCRG. (2016). Kırsal Kalkınma Destekleri Kapsamında Genç Çiftçi Projelerinin Desteklenmesi Hakkında Tebliğ (Tebliğ No: 2016/16). 29675 Sayılı Resmi Gazete. https://www.resmigazete.gov.tr/eskiler/2016/04/20160405-2.htm. Erişim tarihi: 05 Ekim 2020.

Yamane, T. (1967). Elementary Sampling Theory. Prentice-Hall Inc. Englewood Cliffs, s:141, New Jersey. 